\title{
ADULT TIME-MORTALITY RESPONSE AND CHANGES IN REPRODUCTIVE ATTRIBUTES IN CALLOSOBRUCHUS MACULATUS (FAB.) FOLLOWING UV IRRADIATION
}

\author{
M. Saiful Islam* and Sharmin Mustari \\ Department of Zoology, University of Rajshahi, Rajshahi 6205, Bangladesh \\ *Corresponding author; email: saifulzoo@yahoo.co.uk
}

\begin{abstract}
Using 254nm UV radiations of exposure periods from 2 to 16 min against adults. Time mortality response of the cowpea weevil, Callosobruchus maculatus (Fab.) (Coleoptera: Bruchidae), adults and alterations in vital reproductive attributes as fecundity, immature duration, adult emergence and adult longevity of the beetles from parental through $\mathrm{F}_{1}$ generation have been estimated. Time mortality response of the adults of the cowpea weevil Callosobruchus maculatus (Fab.) (Coleoptera: Bruchidae), and alternations in vital reproductive attributes is fecundity, immature duration, adult emergence and longevity from parental through $\mathrm{F}_{1}$ generation using $254 \mathrm{~nm}$ UV radiations of response periods from $2-16 \mathrm{~min}$ have been estimated. Results show that an exposure time to kill $50 \%$ of the adults is around $20 \mathrm{~min}\left(\mathrm{LT}_{50}=19.99 \mathrm{~min}\right)$, and irradiation significantly reduced egg-laying $(\mathrm{P}<0.001)$, lengthened immature durations (i.e. larval and pupal developmental periods; $\mathrm{P}<0.05)$, decreased adult emergences as well as longevity in both sexes $(\mathrm{P}<0.001)$ in the parental generation. The effects of the UV-rays on $\mathrm{F}_{1}$ progenies, however, were less pronounced than that expressed in the parental generation, but the immature duration was significantly increased (P<0.01) but the longevity in both sexes was significantly reduced $(\mathrm{P}<0.001)$. Relevance of this study in relation to prospective phytosanitary treatments of the stored pulses with UV-rays has been discussed.
\end{abstract}

Key words: UV irradiation, Callosobruchus maculatus, time-mortality response, reproductive attributes, stored pulses

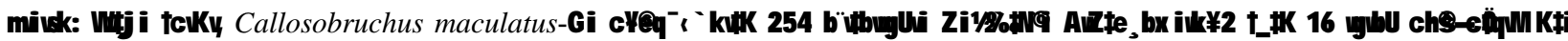

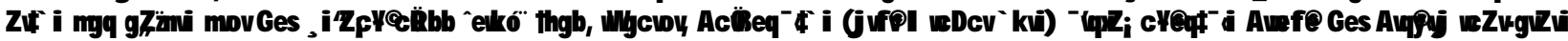

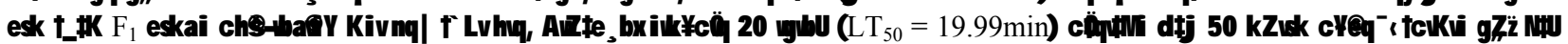

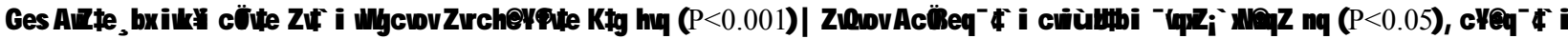

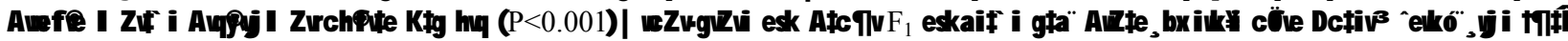

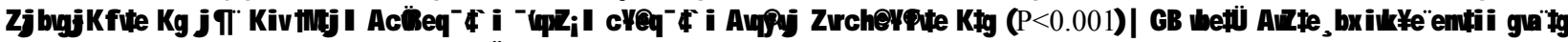

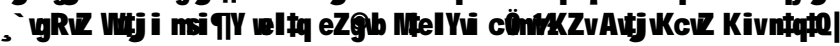

\section{Introduction}

Owing to an alarming threat to the environment and its biota, accompanied by increasing treatment costs and development of resistant strains among the pest population, researchers now-a-days are emphasizing on such alternative approaches as irradiation, phytochemicals, biopesticides, insect hormones and natural enemies instead of traditional and synthetic chemical pesticides (Follett et al. 2007; Begum et al. 2009). These approaches are destined to be nonhazardous to human health, eco-friendly, less expensive, and more importantly, are more specific to the target pest population. Ionizing radiations like $\mathrm{x}$-rays and gamma rays (Islam and Laz 2001; Follett 2006, Follett et al. 2007; Tandon et al. 2009), and non-ionizing radiations like ultraviolet (UV) rays (Islam et al. 1992; Faruki et al. 2005, 2007; Begum et al. 2007, 2009) and microwave radiation (Zhao et al. 2007; Gasemzadeh et al. 2010) have been employed to limit reproduction and survival of a variety of insect pest species. Interest in the use of irradiation as a phytosanitary treatment for agricultural commodities is growing worldwide, particularly since publication of the International Plant Protection Convention (IPPC) standard that endorses and facilitates trade based on this disinfestation method (Follett et al. 2007; Gasemzadeh et al. 2010).

UV-rays are electromagnetic radiation with wavelengths shorter than that of visible light, but longer than X-rays or gamma rays, in the range of 10 to $400 \mathrm{~nm}$ (Harm 1980) that include three main sub-types (Diffey 1991): UV-A or black light (315-400nm), UV-B or medium wave $(280-315 \mathrm{~nm})$, and UV-C or germicidal or short wave $(100-280 \mathrm{~nm})$. The uses of UV irradiation, however, as attractant for the pest insects (Bruce 1975), as germicide (Allen 2001), and as suppressor of immature development and adult emergence in Coleoptera (Calderon et al. 1985; Sharma and Dwevedi 1997; Faruki et al. 2005, 2007; Begum et al. 2007, 2009), in Diptera (Beard 1970; Krishna and Srivastava 1991; Hasan et al. 1998; Khan et al. 2006) and in Lepidoptera (Calderon and Navarro 1971; Faruki and Khan 1993; Faruki et al. 2007) are quite encouraging from pest management point of view. 
Being a major pest of cowpeas (Vigna unguiculata Walp.), black grams (V. mungo Hepper) and other grain legumes, the spotted cowpea weevil, Callosobruchus maculatus (Fabricius) is an important pest of pulses in Africa and tropical Asia both in field crops and in stores (Gorham 1987; Hill 1990). The pest causes damage only at immature stages because the adults normally do not feed in the granaries (Fox et al. 2004). In an elaborate study with C. maculatus and C. chinensis, Mustari (2007) compared efficacies of two wavelengths (254 and $366 \mathrm{~nm}$ ) of UV-rays on pupae and adults, where $254 \mathrm{~nm}$ were found to be much detrimental on adults in both species of the beetle. In the present report, effects of $254 \mathrm{~nm}$ UV-rays for 2 to $16 \mathrm{~min}$ on newly emerged adults, and their consequences on adult mortality, fecundity, immature duration and adult longevity in parents and in the next generation offspring of C. maculatus have been assessed.

\section{Materials and Methods}

Mass rearing of the experimental insects: C. maculatus infested black gram seeds ( $V$. mungo) were procured from wholesale markets of Katakhali, Lashmipur and Shaheb Bazar, Rajshahi, and brought to laboratory for mass rearing. The seeds were kept in $500 \mathrm{ml}$ beakers, mouths were covered with coarse cloth and tied with rubber bands. The beakers were housed in an incubator at $28 \pm 0.5^{\circ} \mathrm{C}$ without light and relative humidity control. After every 10 days fresh seeds, disinfected and sterilized at $60^{\circ} \mathrm{C}$ in an incubator for $24 \mathrm{~h}$ to destroy any previously laid eggs or immature stages, were added to the beakers. In order to eliminate natural and/or deleterious mutations that might have accumulated in their genome over time, the beetles were inbred for two successive generations prior to setting up the experiments.

Estimation of UV-induced adult time-mortality response: A $15 \mathrm{~W}$ germicidal lamp (GE1578) that emitted a wavelength of $254 \mathrm{~nm}\left(1 \mathrm{~nm}=1 \times 10^{-9} \mathrm{~m}\right)$ and installed at the Genetics and Molecular Biology Laboratory, Department of Zoology, Rajshahi University, was used as a source of UV radiation. Time-mortality response tests were conducted with newly emerged adults at a series of irradiation exposure periods viz., 2, 4, 8, 12 and $16 \mathrm{~min}$. For irradiation, 100 anaesthetized or chilled 1-3 day-old adults (1:1 sex-ratio) were kept in $15 \mathrm{~cm}$ diameter Petri dishes, placed on table surface $12 \mathrm{~cm}$ below the lamp and were exposed to UV-rays for estimating their respective mortalities at $24 \mathrm{~h}$ interval up to $72 \mathrm{~h}$ post-irradiation. The same number of non-irradiated insects was maintained as controls. The experiments were conducted in the laboratory at an ambient temperature $\left(25 \pm 2{ }^{\circ} \mathrm{C}\right)$ and normal daylight between 10:00 and 13:00hrs.
Estimation of reproductive attributes: Four reproductive attributes that constitute vital parts in the life-history of an insect viz., fecundity (48h egg-laying), immature duration total number of adults emerged, and longevity of both male and female adults, were considered for assessing UV-induced changes in the experimental beetles. In parental generation, 20 replicates for each treated line $(\mathrm{T} Q+q \times \mathrm{T} O \widehat{\lambda})$ and 10 replicates for the control $\left(\mathrm{C} P Q+\times \mathrm{C} \partial^{\lambda}\right)$ were maintained. C. maculatus that emerged from the parental generation were not further subjected to UV-rays, but they were continued for the $F_{1}$ generation as follows: 5 replicates for each of the treated and control lines were maintained; and apart from the control and treated groups, two reciprocal crosses viz.,

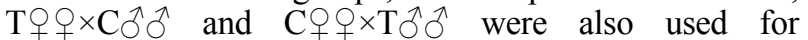
evaluating the reproductive attributes in the progenies. All the experiments were conducted in an incubator at $28 \pm 0.5^{\circ} \mathrm{C}$ without light and relative humidity control.

Statistical analyses: UV-induced time-mortality response data were subjected to Probit analysis (Finney 1964) using a GWBASIC software for estimating an $\mathrm{LT}_{50}$ value i.e the median lethal time to kill $50 \%$ of the treated adults. Then a regression line was plotted based on log time and Probit mortality. Data on reproductive attributes recorded for the parental and $F_{1}$ generations were subjected to one-way analysis of variance (ANOVA), followed by least significant difference (LSD) tests for comparisons between the control and/or treatment groups. A statistical package (SPSS version 11.5 for Windows) was used for analyzing the data.

\section{Results and Discussion}

$U V$-induced time-mortality response in adults: Compared to the control, $72 \mathrm{~h}$ post irradiation adult mortality of C. maculates increased from $10 \%$ at $2 \mathrm{~min}$ exposure period to $50 \%$ at $16 \mathrm{~min}$, thus yielding an estimated $\mathrm{LT}_{50}$ value of $19.99 \mathrm{~min}$ (Fig. 1) and it was positively significant $\left(\mathrm{r}^{2}=0.93, \mathrm{y}=1.48 \mathrm{x}+3.04\right)$. This result suggests that adult mortality in C. maculatus due to UV irradiation, perhaps coupled with inherited sterility, might contribute substantially to the suppression of the pest under laboratory as well as storage conditions.

Effects on fecundity: A significant reduction in egglaying occurred $\left(\mathrm{F}_{5,104}=4.270 ; \mathrm{P}<0.001\right)$ in the parental generation (Table 1) following UV-treatment from $2 \mathrm{~min}$ $(76.20 \pm 19.46)$ to $16 \mathrm{~min}(67.60 \pm 6.61)$ in comparison with the control $(80.00 \pm 11.81)$. In the $F_{1}$ generation (Table 2), however, decrease in fecundity was not significant $\left(\mathrm{F}_{3,76}=0.437 ; \mathrm{P}>0.05\right)$, but oviposition in

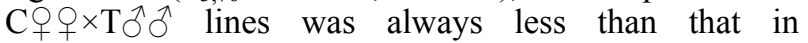

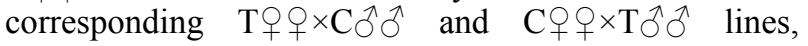
indicating that males of $C$. maculatus are more sensitive to UV radiations than their female counterparts. 


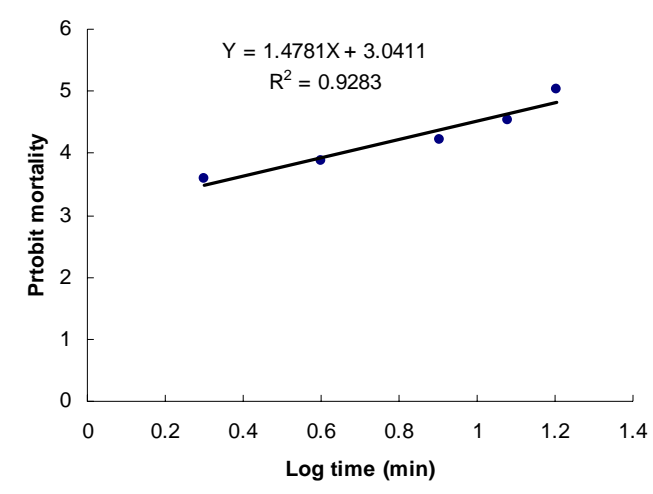

Fig. 1. Adult time-mortality response in C. maculatus following UV irradiation treatments.

Effects on immature duration: The duration of the immature stages (larval and pupal periods) in $C$. maculatus was found to increase significantly both in the parental $\left(\mathrm{F}_{5,104}=2.485 ; \mathrm{P}<0.05\right)$ and $\mathrm{F}_{1}$ generation $\left(\mathrm{F}_{3,76}\right.$ = 4.204; $\mathrm{P}<0.01$ ), showing that UV rays lengthened the immature developmental period up to 4 days (Tables 1 and 2).

Effects on adult emergence: The number of C. maculatus adults emerged from the treated lines in parental generation (Table 1) was gradually and significantly reduced than that in the control lines $\left(\mathrm{F}_{5,104}=10.152 ; \mathrm{P}<0.001\right)$. But this trend was not maintained in the $\mathrm{F}_{1}$ generation $\left(\mathrm{F}_{3,76}=1.957 ; \mathrm{P}>0.05\right)$. While the control had an adult emergence of $57.20 \pm 10.26$, UV irradiation reduced the trait to $28.20 \pm 3.59$ at $16 \mathrm{~min}$ exposure in the parental generation (Table 1), and to $34.18 \pm 5.98$ in $F_{1}$ generation (Table 2).

Effects on adult longevity: Longevities in both the males $\left(\mathrm{F}_{5,104}=11.197 ; \mathrm{P}<0.001\right)$ and females $\left(\mathrm{F}_{5,104}=10.34\right.$; $\mathrm{P}<0.001)$ in $\mathrm{UV}$-treated lines of $C$. maculatus were significantly reduced from about 12 days in the controls to around 8 days in the irradiated female and male beetles in both the parental and $\mathrm{F}_{1}$ generations (Tables 1 and 2).

Treatment effects: Results presented in Tables 1 and 2 clearly demonstrate that $254 \mathrm{~nm}$ UV-rays reduced egglaying, lengthened immature developmental period, decreased adult emergence as well as their longevity in both sexes of $C$. maculatus in an exposure time-dependent manner.

Crossing effects: Compared to the controls

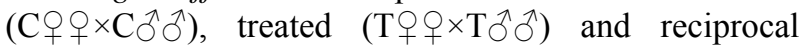

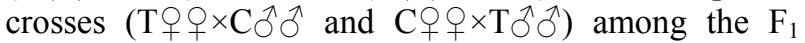
progenies showed only significant lengthening of immature stages and reduction in adult longevity in both the sexes (Table 2), but unlike parental generation, fecundity and adult emergence were not adversely affected.

Generation effects: Comparison of reproductive attributes between the parental and $F_{1}$ generations revealed that UV irradiation in the experimental beetles induced pronounced changes in all life-history parameters in parental generation than those recorded in $F_{1}$. This is suggestive of a diminishing effect of the UV rays on the reproductive attributes of the offspring of the treated grandparents.

Recent uses of gamma irradiation against a number of stored product and other pests (Lester et al. 2003; Hallman 2004; Follett and Armstrong 2004; Follett 2006; Follett and Neven 2006; Follett et al. 2007; Tandon et al. 2009)

demonstrate that unlike other disinfestation techniques, irradiation does not need to kill the pest immediately to provide quarantine security, and therefore live but sterile and/or not viable insects may occur with the exported commodities. Experiments with irradiation other than gamma, for example, microwave radiation and UV rays, for the management of coleopteran pests have shown to be very promising. Zhao et al. (2007) and Gasemzadeh et al. (2010) used microwave irradiation to induce higher mortality and increased developmental stages in the flour beetle Tribolium castaneum and the rice weevil Sitophilus oryzae. Calderon et al. (1985) reported that the egg-hatching in T. castaneum was negatively affected by UV radiation, whereas Sharma and Dwevedi (1997) observed adverse influences of UV-rays on the egg-to-adult development of the pulse beetle C. chinensis. Hoque and Islam (1999) and Islam and Kabir (2000) integrated UV radiation with cytoplasmic incompatibility to suppress population growth in $T$. castaneum, while Faruki et al. (2007) noted that UV treatment in the same insect decreased egg-hatching and reduced adult emergence. The growth and development in the lesser mealworm Alphitobius diaperinus has been shown to be manipulated by UV treatments on eggs, larvae, pupae and adults by a number of workers (Parween et al. 2004; Faruki et al. 2005; Begum et al. 2007). These results nicely corroborate with the findings of the present study.

The present study thus clearly demonstrated the UV irradiated adult time-mortality response, followed by UV radiation-induced alterations in various reproductive parameters in parental through $\mathrm{F}_{1}$ generation in $C$. maculatus. 
Table 1. Effects of adult irradiation with 254nm UV-rays on some reproductive attributes in C. maculatus (Parental generation)

\begin{tabular}{|c|c|c|c|c|c|}
\hline \multirow{2}{*}{$\begin{array}{l}\text { Exposure period }^{1} \\
\qquad(+\odot \times \overbrace{}^{\wedge})\end{array}$} & \multirow{2}{*}{ Fecundity $^{2}$} & \multirow{2}{*}{$\begin{array}{c}\text { Immature duration } \\
\text { (days) }\end{array}$} & \multirow{2}{*}{$\begin{array}{l}\text { No. adult } \\
\text { emergence }\end{array}$} & \multicolumn{2}{|c|}{ Adult longevity (days) } \\
\hline & & & & Females & Males \\
\hline $0(\mathrm{C} \times \mathrm{C})$ & $80.00 \pm 11.81^{\mathrm{a}}$ & $27.98 \pm 2.61^{\mathrm{a}}$ & $57.20 \pm 10.66^{\mathrm{a}}$ & $12.60 \pm 1.14^{\mathrm{a}}$ & $12.00 \pm 1.58^{\mathrm{a}}$ \\
\hline $2(\mathrm{~T} \times \mathrm{T})$ & $76.20 \pm 19.46^{\mathrm{a}}$ & $30.32 \pm 0.44^{\mathrm{a}}$ & $55.20 \pm 12.35^{\mathrm{a}}$ & $7.80 \pm 1.30^{\mathrm{b}}$ & $6.80 \pm 0.84^{\mathrm{b}}$ \\
\hline $4(\mathrm{~T} \times \mathrm{T})$ & $78.80 \pm 6.46^{\mathrm{a}}$ & $30.66 \pm 0.51^{\mathrm{b}}$ & $46.80 \pm 9.04^{\mathrm{b}}$ & $9.20 \pm 0.84^{\mathrm{c}}$ & $8.40 \pm 1.14^{\mathrm{c}}$ \\
\hline $8(\mathrm{~T} \times \mathrm{T})$ & $67.80 \pm 12.15^{b}$ & $30.60 \pm 0.82^{b}$ & $37.60 \pm 11.44^{\mathrm{b}}$ & $8.60 \pm 1.14^{\mathrm{c}}$ & $9.00 \pm 1.58^{\mathrm{c}}$ \\
\hline $12(\mathrm{~T} \times \mathrm{T})$ & $73.20 \pm 3.42^{\mathrm{a}}$ & $30.76 \pm 0.56^{\mathrm{b}}$ & $34.40 \pm 5.94^{\mathrm{b}}$ & $8.40 \pm 1.14^{\mathrm{c}}$ & $8.00 \pm 0.71^{\mathrm{c}}$ \\
\hline $16(\mathrm{~T} \times \mathrm{T})$ & $67.60 \pm 6.61^{\mathrm{b}}$ & $32.16 \pm 1.39^{b}$ & $28.20 \pm 3.59^{c}$ & $8.20 \pm 1.30^{\mathrm{c}}$ & $8.20 \pm 0.84^{\mathrm{c}}$ \\
\hline F-ratios & $4.28 * * *$ & $2.48^{*}$ & $10.05 * * *$ & $11.20 * * *$ & $10.34 * * *$ \\
\hline
\end{tabular}

${ }^{1}$ in min; ${ }^{2} 48$-h oviposition; $\mathrm{C}=$ control; T-treated; Values are mean \pm SD of 10 replicates for control and 20 replicates for each treatment $(\mathrm{N}=110)$; Dissimilar superscripts indicate significant difference by LSD tests at $\mathrm{P}<0.05 ; *=\mathrm{P}<0.05 ; * * *=\mathrm{P}<0.001$.

Table 2. Effects of adult irradiation with $254 \mathrm{~nm}$ UV-rays on some reproductive attributes in C. maculatus ( $\mathrm{F}_{1}$ generation)

\begin{tabular}{|c|c|c|c|c|c|}
\hline \multirow{2}{*}{$\begin{array}{c}\text { Exposure } \\
\text { period }^{1} \\
\left(q Q \times \delta^{\lambda}\right)\end{array}$} & \multirow[b]{2}{*}{ Fecundity $^{2}$} & \multirow{2}{*}{$\begin{array}{c}\text { Immature } \\
\text { duration } \\
\text { (days) }\end{array}$} & \multirow[b]{2}{*}{ No. adult emergence } & \multicolumn{2}{|c|}{ Adult longevity (days) } \\
\hline & & & & Females & Males \\
\hline $0(\mathrm{C} \times \mathrm{C})$ & $76.40 \pm 9.56$ & $28.74 \pm 0.56$ & $52.80 \pm 10.64$ & $12.80 \pm 1.30$ & $12.80 \pm 1.48$ \\
\hline $2(\mathrm{~T} \times \mathrm{T})$ & $74.40 \pm 17.38^{\mathrm{a}}$ & $29.96 \pm 1.80^{\mathrm{a}}$ & $48.87 \pm 19.50^{\mathrm{a}}$ & $10.07 \pm 1.39^{\mathrm{a}}$ & $10.13 \pm 1.55^{\mathrm{a}}$ \\
\hline $2(\mathrm{~T} \times \mathrm{C})$ & $75.11 \pm 10.96^{\mathrm{a}}$ & $28.98 \pm 1.24^{\mathrm{a}}$ & $48.18 \pm 11.01^{\mathrm{a}}$ & $10.98 \pm 0.86^{\mathrm{b}}$ & $9.00 \pm 1.87^{\mathrm{b}}$ \\
\hline $2(\mathrm{C} \times \mathrm{T})$ & $70.09 \pm 7.18^{\mathrm{b}}$ & $29.13 \pm 0.78^{\mathrm{a}}$ & $47.93 \pm 8.12^{\mathrm{a}}$ & $10.01 \pm 0.12^{\mathrm{a}}$ & $9.00 \pm 1.87^{\mathrm{b}}$ \\
\hline $4(\mathrm{~T} \times \mathrm{T})$ & $66.53 \pm 10.50^{\mathrm{a}}$ & $30.35 \pm 0.45^{\mathrm{a}}$ & $38.87 \pm 8.68^{\mathrm{a}}$ & $9.13 \pm 1.25^{\mathrm{a}}$ & $8.67 \pm 1.54^{\mathrm{a}}$ \\
\hline $4(\mathrm{~T} \times \mathrm{C})$ & $64.37 \pm 8.11^{\mathrm{a}}$ & $28.15 \pm 1.33^{\mathrm{b}}$ & $39.17 \pm 9.12^{\mathrm{a}}$ & $9.54 \pm 0.98^{\mathrm{a}}$ & $9.00 \pm 1.12^{\mathrm{b}}$ \\
\hline $4(\mathrm{C} \times \mathrm{T})$ & $60.18 \pm 5.19^{b}$ & $29.84 \pm 0.96^{\mathrm{a}}$ & $40.01 \pm 6.18^{\mathrm{b}}$ & $9.76 \pm 2.01^{\mathrm{b}}$ & $9.12 \pm 0.86^{\mathrm{b}}$ \\
\hline $8(\mathrm{~T} \times \mathrm{T})$ & $68.07 \pm 11.57^{\mathrm{a}}$ & $30.85 \pm 0.66^{\mathrm{a}}$ & $37.07 \pm 7.20^{\mathrm{a}}$ & $9.80 \pm 1.08^{\mathrm{a}}$ & $9.93 \pm 1.28^{\mathrm{a}}$ \\
\hline $8(\mathrm{~T} \times \mathrm{C})$ & $66.13 \pm 12.59^{\mathrm{a}}$ & $28.98 \pm 1.72^{b}$ & $36.84 \pm 8.17^{\mathrm{a}}$ & $9.52 \pm 2.11^{\mathrm{b}}$ & $9.37 \pm 1.14^{\mathrm{b}}$ \\
\hline $8(\mathrm{C} \times \mathrm{T})$ & $62.14 \pm 8.12^{\mathrm{b}}$ & $29.94 \pm 0.55^{\mathrm{a}}$ & $36.11 \pm 9.12^{\mathrm{a}}$ & $8.98 \pm 1.11^{\mathrm{c}}$ & $9.18 \pm 1.10^{\mathrm{c}}$ \\
\hline $12(\mathrm{~T} \times \mathrm{T})$ & $78.40 \pm 7.05^{\mathrm{a}}$ & $32.15 \pm 1.55^{\mathrm{a}}$ & $33.87 \pm 11.29^{\mathrm{a}}$ & $8.73 \pm 1.49^{\mathrm{a}}$ & $9.93 \pm 1.53^{\mathrm{a}}$ \\
\hline $12(\mathrm{~T} \times \mathrm{C})$ & $76.98 \pm 8.11^{\mathrm{a}}$ & $30.12 \pm 0.88^{b}$ & $31.36 \pm 8.12^{\mathrm{b}}$ & $9.08 \pm 1.55^{\mathrm{b}}$ & $9.11 \pm 0.78^{b}$ \\
\hline $12(\mathrm{C} \times \mathrm{T})$ & $60.88 \pm 5.13^{\mathrm{b}}$ & $32.08 \pm 0.97^{\mathrm{a}}$ & $32.57 \pm 10.11^{\mathrm{a}}$ & $8.22 \pm 0.98^{\mathrm{a}}$ & $8.98 \pm 2.01^{\mathrm{c}}$ \\
\hline $16(\mathrm{~T} \times \mathrm{T})$ & $64.27 \pm 10.88^{\mathrm{a}}$ & $33.23 \pm 0.94^{\mathrm{a}}$ & $36.13 \pm 10.26^{\mathrm{a}}$ & $8.93 \pm 1.91^{\mathrm{a}}$ & $9.13 \pm 1.77^{\mathrm{a}}$ \\
\hline $16(\mathrm{~T} \times \mathrm{C})$ & $63.15 \pm 7.85^{\mathrm{a}}$ & $31.92 \pm 0.68^{b}$ & $35.42 \pm 8.17^{\mathrm{a}}$ & $9.01 \pm 0.87^{\mathrm{a}}$ & $9.18 \pm 1.33^{\mathrm{a}}$ \\
\hline $16(\mathrm{C} \times \mathrm{T})$ & $62.14 \pm 8.37^{\mathrm{a}}$ & $32.18 \pm 1.68^{\mathrm{a}}$ & $34.18 \pm 5.98^{b}$ & $8.00 \pm 2.12^{b}$ & $8.88 \pm 2.42^{\mathrm{b}}$ \\
\hline F-ratios & $0.44^{\mathrm{ns}}$ & $4.20 * *$ & $1.96^{\mathrm{ns}}$ & $10.41 * * *$ & $15.58 * * *$ \\
\hline
\end{tabular}

${ }^{1}$ in min; ${ }^{2} 48$-h oviposition; $\mathrm{C}=$ control; T-treated; Values are mean \pm SD of 5 replicates for control and each treatment $(\mathrm{N}=80)$. Dissimilar superscripts within exposure periods indicate significant difference by LSD tests at $\mathrm{P}<0.05$; ns $=$ not significant; $* *=\mathrm{P}<0.01 ; * * *=\mathrm{P}<0.001$.

The present estimated $\mathrm{LT}_{50}$ value suggests that half of the adult beetles in the infested pulse seeds could be killed with $254 \mathrm{~nm}$ UV treatment for $20 \mathrm{~min}$, and reduced longevity of the remaining half, perhaps coupled with inherited sterility, might contribute to reduction in the number of the next generation offspring as shown by the data for $F_{1}$ generation. In agreement with Sharma and Dwevedi (1997) for C. chinensis, Faruki et al. (2005) for A. diaperinus and Faruki et al. (2007) for T. castaneum and $T$. confusum, fecundity, iimature developmental 
stages and adult emergence in C. maculatus were significantly reduced by $254 \mathrm{~nm}$ UV treatments. In addition, as demonstrated by Begum et al. (2007; 2009) for $A$. diaperinus, the present results on lengthened immature duration and reduced number of adult emergence from UV-treated lines are obvious signs of population suppression in C. maculatus under study.

The most likely explanation of the UV irradiation effects on the adult experimental insects is that UV-C at $254 \mathrm{~nm}$ causes adjacent thymine $(\mathrm{T})$ molecules of the DNA strands to dimerize, and further accumulation of these defects inhibits DNA replication, thereby rendering its harmful impacts on the exposed organism (Allen 2001). Adult mortality and reduced longevity in the UV irradiated insects might result from structural changes in the haemolymph as well as reduction in the total haemolymph count as demonstrated in the flesh fly Parasarcophaga ruficornis by Krishna and Srivastava (1991). It may be concluded that the present results are very much encouraging in view of designing an effective phytosanitary treatment protocol against $C$. maculatus that inflicts a considerable damage to a number of stored pulses in many tropical and sub-tropical countries including Bangladesh.

\section{Conclusion}

This study clearly demonstrated UV irradiation induced adult mortality and alterations in various reproductive parameters in parental through $\mathrm{F}_{1}$ generation in $C$. maculatus. Irradiation significantly reduced egg-laying, lengthened immature durations, decreased adult emergences as well as longevity in both sexes. In relation to prospective phytosanitary treatments of the stored pulses with UV-rays, the present findings are promising.

Acknowledgements: This forms a part of doctoral work by the second author, who is thankful to the Chairman, Department of Zoology, RU, for providing necessary laboratory facilities, and to the Ministry of National Science \& Information and Communication Technology (NSICT), Government of the People's Republic of Bangladesh, for financial assistance. For technical help, Mr. Md. Nazmul Haque, Laboratory Attendant of this Department, deserves special mention.

\section{References}

Allen J 2001. Ultraviolet Radiation: How Does it Affect Life on Earth? Earth Observatory, NASA, USA.

Beard RL 1970. Outbred, inbred and hybrid house flies as test insects. J. Econ. Entomol. 63: 229-236.
Begum M, Parween S and Faruki SI 2007. Combined effect of UV-radiation and triflumuron on the progeny of Alphitobius diaperinus (Panzer) (Coleoptera: Tenebrionidae) at different storage period. Univ. j. zool. Rajshahi Univ. 26: 45-48.

Begum M, Faruki SI, Mondal KAMSH, Reza AMS, Naher N, Haque MM and Parween S 2009. Effects of UV-radiation on eggs and triflumuron treated larval food on the duration and formation of life stages of Alphitobius diaperinus (Panzer). Bangladesh j. entomol. 19(1): 41-50.

Bruce WA 1975. Effect of UV-radiation on egg hatch of Plodia interpunctella (Lepidoptera: Pyralidae). J. stored Prod. Res. 11: 243-244.

Calderon M and Navarro S 1971. Effects of ultra-violet irradiation on the eggs of Ephestia cautella (Wlk.) (Lepidoptera: Phycitidae). J. stored Prod. Res. 7: 309311.

Calderon M, Bruce WA and Leesch LG 1985. Effect of UV radiation on eggs of Tribolium castaneum. Phytoparasitica 13: 179-244.

Diffey BL 1991. Solar ultraviolet radiation effects on biological systems. Physics Med. Biol. 36(3): 299-328.

Faruki SI and Khan AR 1993. Potency of UV-irradiation on Cadra cautella (Walker) (Lepidoptera: Phycitidae) larvae treated with Bacillus thuringiensis var. kurstaki. Univ. j. zool. Rajshahi Univ. 12: 73-79.

Faruki SI, Das DR and Khatun S 2005. Effect of UV-radiation on the larvae of the lesser mealworm, Alphitobius diaperinus (Panzer) (Coleoptera: Tenebrionidae) and their progeny. J. Biol. Sci. 5(4): 444-448.

Faruki SI, Das DR, Khan AR and Khatun M 2007. Effects of ultraviolet $(254 \mathrm{~nm})$ irradiation on egg hatching and adult emergence in the flour beetles, Tribolium castaneum, T. confusum and the almond moth Cadra cautella. J. Insect Sci. 7: 1-6.

Finney DJ 1964. Probit analysis: A statistical treatment of the sigmoid response curves. Cambridge University Press, London.

Follett PA 2006. Irradiation as a phytosanitary treatment for Aspidiotus destructor (Homoptera: Diaspididae). J. Econ. Entomol. 99(4): 1138-1142.

Follett PA and Armstrong JW 2004. Revised irradiation doses to control melon fly, Mediterranean fruit fly, and Oriental fruit fly (Diptera: Tephritidae) and a generic dose for tephritid fruit flies. J. Econ. Entomol. 97(4): 1254-1262.

Follett PA and Neven LG 2006. Current trends in quarantine entomology. Annu. Rev. Entomol. 51: 359-385.

Follett PA, Yang M-H, Lu K-H and Chen T-W 2007. Irradiation for postharvest control of quarantine insects. Formosan Entomol. 27: 1-15.

Fox CW, Bush ML, Roft DA and Wallin WG 2004. Evolutionary genetics of life span and mortality rates in two populations of the seed beetle, Callosobruchus maculatus. Heredity 92: 170-181.

Gasemzadeh S, Pourmirza AS, Safarligadeh MS and Maroufpoor M 2010. Effect of microwave radiation and cold storage on Tribolium castaneum Herbst (Coleoptera: Tenebrionidae) and Sitophilus oryzae L. (Coleoptera: Curculionidae). J. Plant Protection Res. 50(2): 140-145. 
Gorham, JR (ed) 1987. Insect and Mite Pests in Food: An Illustrated Key. US Department of Agriculture. Agriculture Handbook No. 655, 767 pp.

Hallman GJ 2004. Irradiation disinfestations of apple maggot (Diptera: Tephritidae) in hypoxic and low-temperature storage. J. Econ. Entomol. 97(4): 1245-1248.

Harm, W. 1980. Biological Effects of Ultraviolet Radiation. Cambridge University Press, UK.

Hasan M, Jahan MS and Khan AR 1998. Effect of UVradiation on the Uzi-fly, Exorista sorbillans Wiedemann, an endoparasitoid of the silkworm, Bombyx mori L. Insect Sci. Applic. 18: 67-91.

Hill DS 1990. Agricultural Insect Pests of the Tropic and Their Control ( $2^{\text {nd }}$ edn.). Mathuens Book Plc., London. 455 pp.

Hoque KMF and Islam MS 1999. Effects of tetracycline and UV radiation treatments on the expression of incompatibility in the red flour beetle, Tribolium castaneum (Herbst) (Coleoptera: Tenebrionidae). Univ. j. zool. Rajshahi Univ. 18: 91-102.

Islam MS and Kabir MA 2000. Integration of cytoplasmic incompatibility with UV radiation and its consequence on the suppression of Tribolium castaneum (Herbst) population. Univ. j. zool. Rajshahi Univ. 19: 43-49.

Islam MS and Laz R 2001. Use of sterile male technique for the control of pulse beetles, Callosobruchus spp. Unpubl. Final Report submitted to the Ministry of Science, Information and Communication Technology, Government of the People's Republic of Bangladesh. 59 pp.

Islam MS, Mannan MA, Begum M, Afreen KS and Saha AK 1992. A preliminary report on the effects of ultra-violet radiation on fecundity and fertility of Culex pipiens fatigans Wiedemann (Diptera: Culicidae). J. Asiat. Soc. Bangladesh, Sci. 18: 57-63.
Khan HS, Islam MS and Salam MA 2006. Effects of UV and gamma radiations on adult recovery and mortality in the housefly Musca domestica L. (Diptera: Muscidae). J. Asiat. Soc. Bangladesh, Sci. 32(2): 283-288.

Krishna K and Srivastava US 1991. Effects of ultraviolet rays on the haemocytes of flesh fly, Parasarcophaga ruficornis F. J. Entomol. Res. 15(1): 378-381.

Lester PT, Rogers DJ, Petry RJ, Connolly PG and Roberts PB 2003. The lethal effects of gamma irradiation on larvae of the Huhu beetle, Prionoplus reticularis: a potential quarantine treatment for New Zealand export pine trees. Entomol. exp. appl. 94(3): 237-242.

Mustari S 2007. UV Radiation Induced Changes in the Life-history Traits of the Pulse Beetles (Coleoptera: Bruchidae). Unpub. $\mathrm{PhD}$ Thesis, Department of Zoology, Rajshahi University. $245+88 \mathrm{pp}$.

Parween S, Faruki SI and Akhter R. 2004. Growth and development of Alphitobius diaperinus (Panzer) (Coleoptera: Tenebrionidae) developing from pupae irradiated with ultra-violet ray. Univ. j. zool. Rajshahi Univ. 23: 23-26.

Sharma MK and Dwevedi SC 1997. Investigation on the effects of ultraviolet and infra-red light on the life cycle of Callosobruchus chinensis Linn. J. Adv. Zool. 18: 27-31.

Tandon S, Singh A and Knaujia S 2009. Effect of gamma radiation on growth and development of rust red flour beetle Tribolium castaneum (Herbst). J. Plant Protection Res. 49(3): 280-282.

Zhao S, Qiu Ch, Xiong Sh and Cheng X 2007. A thermal lethal model of rice weevils subjected to microwave irradiation. J. stored Prod. Res. 43: 430-434.

Manuscript received on 30 June 2010 and revised on 10 November 2010. 